DOI: doi.org/10.21009/IJLECR.051.08

Received: 20 January 2019

Revised: 1 February 2019

Accepted: 12 March 2019

Published: 30 June 2019

\title{
THE DISTINCTION OF LANGUAGE CLASS BETWEEN HIGH AND LOW AFFECTIVE FILTERS
}

\author{
Nurul Annisa Ramdaniyah ${ }^{1, a)}$, Yuniarsih ${ }^{1, b)}$ \\ Suryakancana University, Cianjur ${ }^{1)}$ \\ nunurnul@gmail.com ${ }^{\text {a)}}$,yuniarsihhisra@gmail.com ${ }^{\text {b) }}$
}

\begin{abstract}
Learning language is a process of acquiring language. The successful of learning is influenced by whole aspects of learning such as learning environment. Krashen (1986) suggested, the teacher should create the learning environments as safe and comfort as possible, so all of the input which is given by the teacher can be accept well by the students. Moreover, there is a filter between teacher and student that could become a block input in acquiring language called affective filter. How high or how low the affective filter, it could influence to the learning process. In this study, the researcher tried to find the distinctions between classes with high and low affective filter. This study was conducted in Suryakancana University. The sample was an English class of English Education Study Program. The data gained by observed the class and giving the open-ended questionnaires. The result of the study shows that the class with high affective filter is uncomfortable for the student, and in contrast, the class with low affective filter make students feel comfortable in learning process.
\end{abstract}

Keywords: learning, English class, High Affective filter, Low affective filter

"The limits of my language mean the limits of my world" -Ludwig Wittgenstein

Learning (Robert Gagne, 2000) is a change in human disposition or capability that persists over a period of time and is not simply ascribable to processes of growth. The teaching and learning process is held by teachers and students in the classroom. Learning process can be said to be successful if the teacher can provide material according to the target expected by students. Meanwhile, in the language class learning, especially regarding English which is taught by school in Indonesia (Alawi, 2016), there is a filter (the learners' emotional) that could open or block input process for acquiring language called affective filter (Krashen, 1982). Moreover, this affective filter divided into two sides which are low and high affective filter. In this research, the researcher tries to find the distinction between class with low and high affective filter in an English class. So on, the research questions that appear are:

1. What are the teachers' manner in the class with high affective filter and low affective filter?

2. How the students' responses to each class within high affective filter and low affective filter?

The theoretical framework for this research relies heavily on the work of Steven Krashen (1982). Krashen stated that in learning process, there is a filter (the learners' emotional) which can blocks input necessary for language acquisition. The Affective Filter hypothesis implies that our pedagogical goals should not only include supplying comprehensible input, but also creating a 
situation that encourages a low filter.

According to Krashen (1986), Affective filter is a number of 'affective variables' play a facilitative, but non-causal, role in second language acquisition. These variables include: motivation, self-confidence, anxiety and personality traits. Krashen explained that students, in the process of learning, need to feel safe and comfort, so all of the input which is given by the teacher can be learned well by the students. Class with Low Affective Filter is when the learners have clear motivation, strong self-confidence and measurable anxiety. Different with class with High affective filter, showed by the students who have less motivation to learn, feeling anxious and afraid, also lack of self-confidence. Krashen assumed that when the learners are feeling bored, angry, frustrated, nervous, unmotivated or stressed, they may be unsuccessful at learning a second language.

\section{METHOD}

This research is a descriptive study. Best and Khan (2014) stated that a descriptive study is concerned with conditions or relationships that exist, opinion that are held, processes that are going on, effect that are evident, or trends that are developing. It is primary concerned with the present, although it often considers past events and influences as they relate to current conditions. The aim of descriptive method is to obtain systematically description and accurate facts. It concerns with the collected data that often uses words or sentences.

The researcher observed the English class twice which are taught by two different lecturer. This study also applied open ended questionnaire as the technique in collecting the data.

The responses written in the questionnaire by the respondents according to stundents' perception about the distinction of language class between low and high affective filter. The result data in the questionnaire was used to analysis english teacher with low affective filter and high affective filter.

This questionnaire is used to answer questions for students in their class regarding their opinions on learning activities conducted by english teacher with low affective filter and high affective filter.

\section{RESULTS AND DISCUSSION}

This chapter present the result of analysis. The first data describes The students' perception to english teacher with low affective filter. The second data describes The students' perception to teacher with high affective filter. We got resulted analyze from seven students as samples.

From the observation, the researcher determined the class which is with high or low affective filter. The observation result also used by the researcher to make open-ended questionnaire as the second data for future. The questionnaire result can be seen in the following table.

$\mathrm{X}$ and $\mathrm{Y}$

$\mathrm{X}=$ High Affective filter

$\mathrm{Y}=$ Low Affective Filter 


\section{Table 1. Result of Open-ended Questionnaire}

\begin{tabular}{|c|c|c|c|}
\hline No & Name & Gender & $\begin{array}{c}\text { Result } \\
\text { Analyze }\end{array}$ \\
\hline 1. & $\mathrm{~N}$ & Female & $\mathrm{Y}$ \\
\hline 2. & $\mathrm{R}$ & Female & $\mathrm{Y}$ \\
\hline 3. & $\mathrm{D}$ & Female & $\mathrm{Y}$ \\
\hline 4. & $\mathrm{P}$ & Female & $\mathrm{X}$ \\
\hline 5. & $\mathrm{~A}$ & Female & $\mathrm{Y}$ \\
\hline 6. & $\mathrm{~L}$ & Female & $\mathrm{X}$ \\
\hline 7. & $\mathrm{Y}$ & Female & $\mathrm{Y}$ \\
\hline
\end{tabular}

Based the results that gained from two ways of data analysis, the researcher try to answer the questions. The first data is from observation. In the learning process, each class show the contrast situation. The students show the activeness in the class with teacher Y, and in the other hand, the class with teacher $X$ more Silent. Then, according to the theory that reveal before, the researcher categorized that Class $Y$ as class with low affective filter and Class $X$ as class with high affective filter.

The second is the data that gained from open-ended questionnaire which is shared to seven students as samples. From the data the researcher answer questions, first question is teacher's manner in the classroom. Depends on the students' perception, teacher $\mathrm{X}$ in the classroom are boring, explisit, can't understandable and make the situation quiet tense. Meanwhile, the teacher Y in the classroom are Humble, maturnity, comfortable, understandable, slow and make the class active. Next is the second question about students responses to the teachers' manner. The students statement about learning in the class with teacher $\mathrm{X}$ are most of the students feel lose interest, feel tense and apathetic, then the effect is they unwilling in giving opinion. In the other words, the students are unmotivated to learn in the class X. In contrast, students are enthusiast, comfortable, focus, and active in giving opinion when they learn in the class Y. From the result above, the data are supportig each other and related to the theories. The responses of the students to the Class $\mathrm{X}$ also indicate that Class $\mathrm{X}$ has high affective filter and Class $\mathrm{Y}$ has low affective filter.

\section{CONCLUSION}

From the data analysis that has been done, we can conclude that students of Suryakancana University especially in english education study program prefer to teacher with low affective filter. Factors that influence this include the delivery of learning carried out by the teacher, as well as the environmental factors of the students that make the learning process more comfortable for teacher with low affective filter. From the point of view of students on how to convey by teachers with low affective filters well understood because the learning process is not tense, and the teacher is very humble to students in the class so that it increases motivation to learn and plays an active role in class, whereas for teachers with high affective filters when the learning process is in class not easily understood by students, the main factor is the high level of student anxiety because the teacher is so unpleasant that students are not motivated to learn.

\section{REFERENCES}

Alawi, T. (2016). The Social And Affective Dimensions Of Early Second Language Acquisition: A Case Study.Philiphines : International Journal of Education and Research 
Sulistiani. (2014). The Effect Of Affective Filter Towards Students Motivation. Indonesia : Unversitas Siswa Bangsa Nasional

Iris \& Willbanks. (2013). The Affective Filter Hypothesis. USA : Seattle University

Xu min. (2016). The Application of Input Hypothesis and Affective Filter Hypothesis in Colleges English Listening Teaching.China : GZ Vocational College of Science and Technology

Patten and Wlliams. (2015). Theories in Second Language Acquisition.Chicago : Michigan State University

Krashen. (2002). Second Language Acquisition and Second Language Learning.USA : University of California

Larsen, K. (2014). Affective Filter in Second Language Learning in South Korea. South Korea : Hankuk University of Foreign Studies Seoul Campus 